\title{
DAS LIMITAÇÕES LEGAIS AO DIREITO DE PROPRIEDADE
}

\author{
Luiz Fernando Coelho

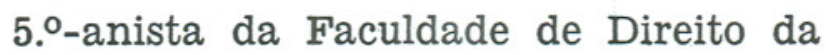 \\ Universidade do Paraná.
}

(Resumo da tese, aprovada com Menção Honrosa na $\mathbf{X}^{\mathrm{a}}$. Semana Nacional de Estudos Jurídicos, realizada em Fortaleza, e Medalha de Ouro na 3. a Semana Paranaense de Estudos Jurídicos e Sociais).

\section{SUMARIO}

1 - Generalidades. Fundamento das Limitações.

2 - Limitações ao Direito de Propriedade no Direito Constitucional Brasileiro.

3 - As Limitações no Código Civil e na Legislação Complementar.

4 - O Conteúdo Jurídico das Limitações.

5 - Considerações Finais e Conclusão.

1 - Pois que todos os direitos existem em harmonia como parte de unidade orgânica, não há que falar, "lato sensu", em direito absoluto ilimitado; a limitação dos direitos é necessidade imperiosa para sua perfeita reunião nas pessoas que os exercem. Se assim não fôra, fatalmente entrariam em choque com idênticos direitos reunidos em outra pessoa. Tais considerações, de ordem prática, só por si já salientam a necessidade das restrições impostas ao exercício dos direitos subjetivos. Em relação ao direito de propriedade, antes de entrarmos na análise de suas limitações, impõe-se a prévia determinação dos setôres onde se aplica, o objeto material desta relação jurídica. Objetivamente, trata-se de sua aplicação às coisas incorpóreas, já que pacìficamente se pode aceitá-la às coisas materiais. Os romanos não estabeleceram a distinção lógica dos têrmos com os quais definiam o poder de direito sôbre o objeto. As expressões "dominium" e "proprietas" eram tomadas em idêntico sentido, com a mera diferenciação referente ao maior ou menor emprêgo pela técnica jurídica. Ambos 
significavam o poder geral e absoluto sôbre a coisa corpórea, muito embora, no concernente ao instituto jurídico da posse, tenha havido uma evolução no sentido de sua extensão às coisas incorpóreas, aos "jura in re aliena", malgrado a distinção vocabular pela designação desta sub-categoria do instituto de "quasi-possessio". Não estabelecendo diferenciação entre "dominium" e "proprietas", quer no objeto, quer no âmbito, não aplicaram os romanos o direito de propriedade às coisas imateriais.

Hodiernamente, a técnica jurídica estabelece distinções, necessárias à determinação do âmbito de incidência do instituto. De um modo geral, o domínio é considerado a espécie de que a propriedade é o gênero. PONTES DE MIRANDA distingue pelo menos três sentidos em nossa legislação, ora referindo-se à propriedade como incluindo o domínio ou qualquer direito patrimonial, ora considerando-a "todo direito irradiado em virtude de ter incidido regra do direito das coisas", ora como "todo direito sôbre as coisas corpóreas, mais a propriedade científica, literária, artística e industrial". E um quarto sentido, mais usado em ciência, "empregado quando se fala no proprietário em relação a outro titular de direito real, é sòmente o domínio, em sentido estritíssimo" (1). AMBROISE COLLIN e CAPITANT negam em princípio tal amplitude ao têrmo, pois, "dans son sens précis et téchnique, la propriété ne porte que sur les choses corporelles, meubles et immeubles". Vêem um sentido metafórico da palavra sua aplicação às coisas incorpóreas, pois "dans un sens plus étendu et que nous pouvons qualifier de métaphorique, la notion et le mot de propriété ont été appliqués à des droits tout differents, à des biens incorporels notamment..." (2). O professor da Universidade de Berlim, MARTIN WOLFF ( esquematiza o direito de propriedade no seu elemento objetivo excluindo as coisas incorpóreas (3). Entretanto, em que pese os esforços do jurista em preservar o sentido real e tradicional do têrmo, e fato consumado a sua extensão, no Direito Moderno, à propriedade literária, artística e científica, valendo isto como a prova irrecusável da extensão do instituto às coisas imateriais. Levantam-se objeções a êste critério, baseando-se-os em o não reconhecimento de certas características fundamentais ao direito de propriedade, quando aplicado às coisas incorpóreas, como sejam, a exclusividade e perpetuidade. O primeiro dêstes caracteres, porém, não se dissolve totalmente dentro da destinação normal das produções intelectuais ao uso das pessoas, porque persiste envolvida no direito de sòmente o autor poder reproduzir a obra, e na obrigação passiva universal, "erga omnes", de respeito ao conteúdo das idéias e imagens traçadas. Em relação à perpetuidade, não deriva ela de nenhuma noção fundamental da propriedade, mas de uma disposição de Direito Po-

(1) P. de MIRANDA: Tratado de Direito Privado, 2. ${ }^{n}$ edi., vol. XI, p. 9.

(2) A. COLLIN e H. CAPITANT: Cours Elémentaire de Droit Civil Français, 7a. ed. 1932, p. 139.

(3) M. WOLFF: "Derecho de Cosas", vol $3 .^{\circ}$ do ENNECCERUS, KIPP, WOLFF: "Tratado de Derecho Civil", trad. de Gonzalez e Alguer. 1936, p. 297. 
sitivo; e a mesma surge delimitada pelas restrições legais, sendo que a duração dos direitos reais varia no tempo e no espaço, conforme as legislações.

A presença de limitações ao Direito de Propriedade pode-se notar em tôdas as fases de sua evolução, mesmo dentro das codificações que lhe traçaram o caráter de direito ilimitado. É pura impossibilidade lógica o caráter antisocial que se julgou encontrar no "jus abutendi" da conceituação romana, dentro da definição elaborada pelos comentadores do Direito Romano. Baseados na interpretação literal da expressão, influenciados pela palavra correspondente nas línguas néo-latinas, mais o individualismo que, de um modo geral, caracteriza $o$ direito das coisas dos romanos, muitos têm-no entendido de maneira errônea, quando não absurda; sòmente isolado do contexto se justifica tal interpretação, vulgarizada pela tradução literal ensinada aos jovens cultores da ciência do Direito. O caráter anti-social da propriedade romana, além de não corresponder à lógica jurídica, é contradito pelas inúmeras restrições legais, que a mostram subordinada ao bem estar social. Naturalmente, a extensão dêste conceito entre os romanos não era na mesma proporção que o é hoje, registrados històricamente exemplos de que o poder individual impedia até mesmo a construção de estradas e outras obras necessárias. Entretanto, salvo casos esparsos motivados pela aristocracia romana, o interêsse geral prevalecia, com a inclusão de inúmeras limitações ao direito individual, surgidas pelas exigências de ordem social. E a re- gra do "quatenus juris ratio patitur" confirma êste raciocínio, com o qual não concorda PROUDHON, imaginando a citada regra "distinction vaine, imaginé pour la sanctification de la propriété" (4). Razões de ordem filológica, entretanto, confirmam o real sentido do "jus abutendi", tal como o encara a lógica jurídica. Indica o termo, além do que o "usus" implica, particularmente o direito de consumir com a coisa, porém sempre dentro da regra do "quatenus juris ratio patitur".

Nem mesmo o Código Napoleônico, impregnado do exagerado espírito liberalista ditado pela violenta revolta burguesa contra o regime feudal, e que tão bem reproduziu o espírito individualista do Direito Romano, deixou de aplicar as limitações, reduzindo sensìvelmente o âmbito da idéia que sua definição comportava. Muito embora o definisse como o direito "le plus absolu", restringiu-o com a romana idéia do "quatenus juris ratio patitur", traduzida no direito francês pela expressão "pourvues qu'on en fasse pas un usage prohibé par les lois ou par les réglements".

Do ponto de vista filosófico jurídico, é a doutrina da função social da propriedade que tem procurado sistematizar os fundamentos ontológicos desta relação jurídica. Mas a própria definição de função social gera intermináveis polêmicas, resvestindo-se de diferentes caracteres de acôrdo com a doutrina ou ideologia que se atribui o tê-la suscitado. Não cabe aqui a crítica de cada uma destas

(4) P. J. PROUDHON: “Qu'est-ce que la Propriété”, t. ler. Paris, 1873, p. 37. 
doutrinas, mas limitamo-nos a expor o nosso pensamento a respeito. Inútil se nos apresenta a polêmica levantada pelo Positivismo Jurídico, conceituando o fato social como suficiente fundamento da relação jurídica. Bastaria à moderna Ciência do Direito fazer ressurgir o multi-secular patrimônio da obra tomista, na pureza do seu Jusnaturalismo, sem os exageros do Racionalismo de Descartes a Kant. A função social da propriedade não é monopólio da Filosofia do Direito de nossos dias. TOMAS d'AQUINO a expõe com perfeição e inigualável clareza. $\mathrm{Na}$ concepção do AQUINATE, a função social não é considerada o fundamento absoluto do direito subjetivo à propriedade, ao contrário da concepção de DUGUIT, mas um critério formal, complementar, deduzido, como o próprio fundamento jusnaturalístico do instituto, da compreensão dos elementos que constituem a personalidade humana. A função social é o fundamento das limitações ao direito, derivando da própria natureza humana social. Considera o DOUTOR ANGÉLICO, inicialmente, o poder de gestão e disposição das coisas, "potestas procurandi et dispensandi", e o poder de uso e fruição. Quanto a êstes, não é lícito ter as coisas como próprias, mas comuns, de modo que fàcilmente dê participação nelas aos outros, quando o necessitem (5). Eis a síntese do Jusnaturalismo de TOMAS D' AQUINO. O fundamento do direito de propriedade é a ordem natural, sendo exigência da natureza animal, racional e social humana. Êste último aspecto determina a função social da propriedade, fun- damento das limitações legais ao direito subjetivo.

No Direito Brasileiro, as limitações são ditadas ora pelo interêsse público, ora pela harmonização dos interêsses privados.

2 - A história do Direito Constitucional Brasileiro nos mostra claramente as diretrizes que nortearam a evolução do instituto da propriedade em nosso país. O sistema europeu, configurado no Feudalismo, com algumas variações, é a regra seguida anteriormente à Independência. A dominialidade pública é a forma primeira de que se reveste jurìdicamente a propriedade, pois todo o território da colônia pertencia, originàriamente, ao poder público, na pessoa do rei de Portugal. Daí se processou a transferência para particulares, de acôrdo com os princípios jurídicos em voga.

A Constituição Imperial de 1824, em seu art. $179, \& 2 .^{\circ}$, dispunha: "É garantido o direito de propriedade em tôda a sua plenitude. Se o bem público, legalmente verificado, exigir o uso e emprêgo da propriedade do cidadão, seja êle prèviamente indenizado do valor dela". Já a Constituição Republicana de 1891 dispôs: "O direito de propriedade mantém-se em tôda a sua plenitude, salvo a desapropriação por necessidade ou utilidade pública, mediante a indenização prévia (art. 72, § 17). Observa CARLOS MAXIMILANO, o grande comentarista de nossa Constituição, que, "na vigência da Constituição de 1891, cujos princípios

(5) Sto. TOMAS D'AQUINO: “Suma Teologica”, 2.2 q. 66 a.2. - Ed. Biblioteca de Autores Cristianos, Madrid, MCMLVI. 
fundamentais, em matéria de Economia, advieram da Inglaterra $\mathrm{e}$ da República de Washington, não se admitiria o Estado industrial ou comerciante (6).

O govêrno provisório enviou, em 1933, à Assembléia Nacional Constituinte, o projeto Itamarati, que rezava:

"Art. 144 - É garantido o direito de propriedade, com o conteúdo e os limites que a lei determinar.

$\S 10^{\circ}$ - A propriedade tem, antes de tudo, uma função social, e não poderá ser exercida contra o interêsse coletivo".

Note-se a nítida preocupação do legislador em fundamentar as disposições legais. Mas a arrojada concepção não foi aceita, ou compreendida, pelo mundo jurídico brasileiro da época, formada no espírito individualista do Direito Francês, preferindo-se uma fórmula mais moderada, que apenas indicasse a necessidade das limitações, sem a preocupação de fundamento, mesmo porque tal estabelecimento poderia suscitar controvérsias de ordem doutrinária entre os juristas. Assim, estabeleceu a Constituição de 1934: "é garantido o direito de propriedade, que não poderá ser exercido contra o interêsse social ou coletivo, na forma que a lei determinar". A Carta de 1937 em pouco modificou o Estatuto: assegura o direito de propriedade, mas "o conteúdo e os seus limites serão definidos nas leis que lhe regularem o exercício" (art. 122, § 14).

A atual Constituição continua a linha das anteriores, fazendo, porém, questão de fundamentar expressamente as limitações. As- sim, reza 0 art. 141, \& 16: E garantido o direito de propriedade, salvo o caso de desapropriação por necessidade, utilidade pública, ou por interêsse social, mediante prévia indenização em dinheiro. Em caso de perigo iminente, como a guerra ou comoção intestina, as autoridades competentes poderão usar da propriedade particular, se assim exigir o bem público, ficando, todavia, assegurado o direito de indenização ulterior. $\mathrm{E}$ o art. 147 dispõe: "O uso da propriedade será condicionado ao bem estar social. A lei poderá, com observância do disposto no $\$ 16$ do art. 141, promover a justa distribuição da propriedade, com igual oportunidade para todos".

A Constituição de 1946, em matéria de propriedade, foi a que melhor reproduziu as idéias da época em que vivemos. Sua insistência no pensamento do interêsse social, na indenização e na desapropriação o demonstram. Em relação aos estatutos anteriores, constitui uma inovação quase que revolucionária a idéia da desapropriação por interêsse social, obra do Senador FERREIRA DE SOUZA, em famosa emenda; note-se que "interêsse social" é conceito bem mais amplo que "necessidade ou utilidade pública", pois que estas dão uma idéia de imediatismo em relação às causas que determinam a desapropriação, enquanto que isto não existe necessàriamente no âmbito do primeiro termo. O eminente homem público justificou-a pelos princípios da Doutrina Social Cristã, que impõe ao proprietário obrigações de ordem

(6) CARLOS MAXIMILIANO: "Comentários à Constituição Brasileira de 1946", 4.a ed. vol. III, 1948, vers. 590. 
moral. O autor defendeu a função social da propriedade e exigiu sua utilização ao bem comum (7). O decreto-lei n. 3.365 , de 21-6-41, veio regular a matéria constitucional quanto à desapropriação; assim é que, no art. $5 .^{\circ}$, prevê os casos considerados de utilidade pública, em maior escala do que o fizera antes o Código Civil, sem discriminar entre necessidade e utilidade pública.

A desapropriação tem por pressuposto única e exclusivamente o Bem Comum, a utilidade pública no mais amplo sentido. Por isso não se a tolera em benefício de particular, de indivíduos ou de uma classe, ainda que indiretamente sejam úteis à coletividade. O texto Constitucional formula uma única exceção, configurada nos dispositivos do art. 147, que permite até a desapropriação de latifúndios improdutivos e redistribuição das terras ao pequeno agricultor.

Obriga a Constituição ao pagamento de indenização por parte do poder público; não se trata aqui de mero ressarcimento por perdas e danos, mas de substituição de um bem jurídico por outro equivalente, o valor monetário do objeto desapropriado. A Constituição exige que ela seja feita em dinheiro, moeda corrente. Melhor seria que o Estado fizesse o pagamento da indenização da maneira que melhor lhe conviesse; é reconhecido que tal dispositivo representa, de certa forma, um impecilho à prática da desapropriação; entretanto, a possibilidade do abuso da autoridade fez a opção por esta forma. Comenta MAXIMILIANO que a Assembléia Constituinte consolidou êste preceito em virtude do fato de governos locais imporem a indenização em apólices: a própria circunstância de emissões para as despesas com expropriações numerosas ocasiona a queda da cotação dos títulos, do que resulta prejuízo para os tomadores obrigados (8).

$\mathrm{O}$ preceito tem sido apontado como grande impecilho para a reestruturação da vida agrária brasileira, a exigir urgentemente a redistribuição da propriedade rural, latifundiária, e o aumento de restrições que impeçam o abuso dos proprietários rurais. O impecilho na verdade não é tão grande como parece. Nada justificaria mais um empréstimo ou emissão do que uma reforma agrária. Além disso, algumas medidas prévias viriam solucionar, ao menos parcialmente a questão, como a interferência estatal prévia na propriedade agrícola privada, como fase preliminar à desapropriação, mudando-lhe a destinação econômica, com ônus aos proventos. Finalmente, antes do sacrifício que se imporá aos cofres públicos, cumpre lembrar que muito maior sacrifício representa a demora na solução dos problemas agrários.

3 - O Código Civil Brasileiro tem feição individualista; assim é que, adotando os moldes do Código de Napoleão, inspirando-se na fonte romana, o "domínio presume-se exclusivo e ilimitado, até prova em contrário" (art. 527). "A lei assegura ao proprietário o direito de usar, gosar e dispor de seus bens, e de reavê-los do poder

(7) V. Diário da Assembléia de 3-5-46, pag. 1435 .

(8) CARLOS MAXIMILIANo. op. ct. pag. 104. 
de quem quer que injustamente os possua" (art. 524). Critica-se a falta de uma definição objetiva do direito de propriedade, entretanto isto não tem procedência, pois que o texto legal põe a salvo justamente a objetividade que é imperioso em matéria de direito civil. Não cometeu nosso legislador o êrro dos autores do Código Napoleônico e do Código Italiano de 1865; tais definições não escaparam às fundadas críticas dos exigentes pesquisadores do Direito Civil, provando que "omnis definitio in jure civile periculosa est".

A exemplo dos códigos alemão e suisso que respectivamente nos artigos 903 e 641 referem-se ao proprietário, cujos direitos declaram, nosso código, sòbriamente, enumera os elementos que compõem o direito de propriedade, reunindo-os na pessoa do proprietário: uso, gôso, disposição da coisa e reivindicação; e de acôrdo com o preceito constitucional, estabelece o conteúdo dêsses direitos e os limites dentro dos quais devem ser exercidos.

Ao passarmos a enumerar as limitações do direito de propriedade no código civil, mistér se faz, antes de tudo, a distinção perfeita entre o âmbito das idéias de limitação legal e de propriedade limitada, nos termos do art. 525. Em oposição à plena propriedade, opõe o citado artigo a propriedade limitada, aquela em que há ônus real ou é resolúvel.

Em sentido amplo, a limitação é a que a lei estabelece ao pleno exercício do direito, consideradas tôdas as suas características reunidas na pessoa do sujeito; assim, a restrição imposta legalmente atinge o direito "in totum", con- siderado em todos os seus elementos; por outro lado, na propriedade limitada, ou é o sujeito do direito subjetivo que se desfaz, voluntàriamente, de algum dos elementos que o constituem, transferindo-o a outrem, ou se insere, no título de constituição dominial, o princípio extintivo da propriedade. No primeiro caso temos a propriedade limitada por ônus reais. São categoria aparte de limitações, que poderíamos chamar de voluntárias, de vez que dependem mais de acôrdo de vontades do que, pròpriamente, de imposição da lei.

Os ônus reais que podem limitar a propriedade são os chamados "jura in re aliena", de que tratam os artigos 674 e seguintes do Código Civil. Mas no que se refere aos direitos reais de garantia, opina SÁ PEREIRA que, "a propriedade, a rigor, não se pode denominar limitada, mas tão sòmente onerada" (9). O segundo tipo de propriedade limitada é o configurado no domínio resolúvel, aquêle em que, no próprio título de sua constituição, se encerra o princípio que o tem de extinguir, realizada a condição resolutiva, ou 0 termo extintivo.

Entre as limitações de caráter voluntário encontram-se as decorrentes da cláusula de inalienabilidade; não se trata de proibição legal da alienação de certos bens, em virtude de sua destinação, mas daquela proibição que é resultante do próprio título que acompanha a coisa, quando o proprietário a recebe por doação ou herança; ela é estipulada nas transmissões a

(9) ap. Carvalho Santos: "Cod. Civil Bras. Interpretado", vol. VII p. 298. 
título gratuito, pois se as não justifica naquelas a título oneroso.

O Código Civil estabelece expressamente inúmeras limitações ao direito de propriedade, considerada esta no seu todo, e que, em geral, vão atingí-lo em relação ao elemento "usus".

Em primeiro lugar estão as decorrentes das relações de vizinhança. LACERDA DE ALMEIDA, na classificação que faz das limitações, contrapõe esta categoria às de direito público, isto é, decorrentes de disposições de ordem administrativa e policial; as derivadas das relações de vizinhança constituiriam restrições de direito privado (10). Êstes "jura vicinitatis" não constituem, porém, categoria aparte de limitações. Preferimos não nos ater à classificação do mestre, tomando-as no sentido mais amplo, não importando que outro aspecto jurídico possam ter, já que limitações existem que são simultâneamente modos de aquisição e perda da propriedade imóvel, conforme as considerarmos em relação aos sujeitos que entram em pauta na configuração dos mesmos, quando existe um que é beneficiado e outro prejudicado. Igualmente, é árdua tarefa enumerar tôdas as limitações. Fá-loemos no tocante às principais, mais ou menos na ordem em que se apresentam no texto legal. São as seguites: a) o proprietário não se pode opor a trabalhos em tal altura ou profundidade que lhe não prejudiquem a propriedade (art. 526); b) certas modalidades de acessão, em relação ao proprietário do terreno eventualmente prejudicado (art. 547); c) o usocapiắo poderá eventualmente tornarse restrição ao direito de proprie- dade, em relação a provável anterior proprietário (art. 550, 551, 619 e 698); d) o direito de passagem, quando assiste a prédios encravados (art. 559); e) as disposições sôbre a passagem das águas (art. $563)$; f) as servidões de direito e regulamentos administrativos (art. 572 e seguintes); g) as consequências jurídicas do abandono da propriedade imóvel (art. 598, \& 2. ${ }^{\circ}$ ); h) certos casos de ocupação de bens móveis (art. 592); i) subordinação à vontade da maioria nos casos de condomínio (art. 635); j) certas disposições protetoras de família, como as que impossibilitam as doações do cônjuge adúltero ao seu cúmplice (art. 1.177); as que cominam pena de nulidade para a doação de todos os bens, sem reserva de parte, ou renda suficiente para a subsistência do doador (art. 1.175).

A legislação especial e a jurisprudência vieram completar a série de restrições legais. A exemplo do Direito Romano, existem limitações de natureza militar e as decorrentes das leis eleitorais. Há também que considerar os casos em que a lei obriga o proprietário à construção de benfeitorias, obras estas que só aproveitam à propriedade, e, objetivamente, a não prejudicam, motivando tal aspecto, por parte de alguns, a exclusão de tal categoria do número de restrições ao direito de propriedade. Inicialmente, se tal fôsse, inúmeras restrições deixariam de sê-lo, pois que sòmente vêm a aproveitar à propriedade, sem causar-lhe prejuízo. Entretanto, apesar do benefício ao objeto material do direito,

(10) LACERDA DE ALMEIDA: "Direito das Coisas" Rio, 1908, pag. 104. 
como, por exemplo, quando a lei obriga à construção de benfeitorias por motivo de higiene, não deixa isto de ser uma limitação legal ao direito de propriedade, pois o que se tem em vista ao tratar dêsse assunto não é o objeto, mas o direito em si, considerado quanto à sua amplitude. E, nestes casos, não deixa de ser a imposição legal uma limitação que visa o elemento livre disposição, pois que, a rigor, esta significa o direito ou faculdade subjetiva de dispor da coisa de acôrdo com o próprio entendimento, e não sujeita ao texto legal; entretanto, a lei surge exatamente para impedir apriorísticamente o máu uso da propriedade. A obrigatoriedade da construção de benfeitorias não se constitui, pois, em exceção. Apenas realiza a restrição no sentido de benefício ao proprietário, mas de modo secundário, pois em primeiro plano está o interêsse da comunidade. Surge aqui um problema quanto ao sujeito sôbre o qual recai tal limitação, ou, no exemplo específico de que estamos tratando, quanto ao sujeito encarregado de realizar as benfeitorias obrigatórias, se considerarmos a pessoa do possuidor, em relação ao proprietário.

O possuidor, como no caso do locatário, tem o poder fático sôbre a coisa, exercendo, por conseguinte, os direitos subjetivos que constituem elementos do direito de propriedade. Entretanto, o proprietário tem o poder de direito. Atinge, pois, a limitação direito do proprietário ou direito do possuidor, que exerce o usus? A lógica jurídica afirma que ao proprietário compete, e a jurisprudência tem confirmado, por exemplo, nos ca- sos em que as ditas obras são de exigência da saúde pública. BENTO DE FARIA fundamenta esta opinião considerando que "a medida de higiene é imposta ao prédio como condição de sua habitabilidade". Por outro lado, considera que por tais obras não pode ser responsável o morador, obrigado tão sòmente à limpesa e conservação das mesmas" (11). De um modo geral, é suficiente considerar que o poder fático do possuidor tem caráter transitório, enquanto que o poder de direito do proprietário tende naturalmente à perpetuidade, para se compreender da certeza da assertiva.

É imenso o número de limitações legais ao direito de propriedade; encontram-se espalhadas em diversos regulamentos administrativos e decretos; e a jurisprudência vem acumulando, em inúmeras decisões, uma série de restrições que muitas vêzes não são expressamente previstas nos textos legais, mas que se vão consagrando em nome dos princípios mesmos que levaram o legislador a instituí-las, os princípios de justiça e de eqüidade, sempre dentro da lógica do direito.

4 - Nesta incursão através do vasto campo do Direito Positivo Brasileiro, observamos profundas modificações na concepção da Propriedade, de acôrdo com as mudanças sociais a que nosso povo não esteve alheio. Inicialmente, notamos a repercussão das doutrinas liberalistas, e no momento em que profundas mudanças foram introduzidas no conceito in-

(11) BENTO DE FARIA: "Pareceres", ed. Imprensa Nacional, 1933, I, p. 191. 
dividualista e clássico da propriedade, e que abalaram os alicerces jurídicos de todos os países civilizados, repercutiram, de forma renovadora, em nosso Direito Positivo, notadamente a partir de 1930, que foi como que um divisor de águas na vida política e econômica brasileira. A Constituição de 1946 consagrou definitivamente o conceito vasto e social do instituto, seguindo o exemplo de outras nações que o impuseram em seu edifício jurídico, apezar da sistemática oposição dos liberais burguezes e dos conservadores dos mais variados matizes. Diz PONTES DE MIRANDA, que "ao legislador só se impede acabar, como tal e em geral, com o instituto jurídico, com o Direito de Propriedade". E, adiante, "a propriedade tem passado, desde o terceiro decênio do século, por transformações profundas, às quais ainda se não habituaram os juristas, propensos à só consulta do Código Civil, em se tratando do Direito de Propriedade" (12). Tanto quanto a Constituição de 1946 adotou a concepção social do instituto, o Código Civil consagrou as tendências filosóficas do liberalismo individualista. Indiscutivelmente, a perfeição de suas linhas clássicas o tornam modêlo de técnica jurídica, mas não impede que esteja divorciado da realidade nacional. Isto leva a atribuir uma certa senilidade ao estatuto. Existe, assim, uma situação delicada no atual panorama jurídico, ou seja, uma ordem jurídica de cunho individualista mantendo os germes dos princípios do socialismo jurídico. Entretanto, sob a égide constitucional, a legislação complementar vai aos poucos tornando obsoleto, alterando-lhes as disposições individualistas. Já no que se refere à propriedade do solo, o Código Civil estabelece que esta abrange a do que lhe está superior e inferior em tôda a altura e em tôda a profundidade úteis ao seu exercício, e apenas opõe a restrição de permitir que se realizem trabalhos a uma altura ou profundidade tais que não tenha interêsse em impedí-los (art. 526). A atenta exegese anula pràticamente tal limitação, pois que o texto acondicionado ao interêsse do proprietário. Mas eis que atualmente, o subsolo já não pertence ao proprietário do solo: o proprietário de um fundo rural, sem deixar de ser dono, vê-se despojado das jazidas minerais do subsolo, ou da cachoeira que aciona uma turbina; o Código de Minas, o Código Brasileiro do Ar, bem como o de águas e o de águas minerais, fixam disposições que limitam o direito de propriedade no sentido vertical. O Código Florestal, o Código de Caça e Pesca, por sua vez, introduzem certas restrições à propriedade do solo. A exegese não necessitará ser muito profunda para que se conclua o fundamento de tais limitações, o interêsse coletivo e que o legislador vem assimilando a doutrina da função social da propriedade cada vez com maior intensidade. A enumeração poderia prosseguir, porém os poucos exemplos citados mostram a caducidade atual do sistema do Código, em se tratando de propriedade, e delineam claramente a tendência atual do Direito. Adotando a imagem de JOSE AUGUSTO CÉSAR: "podemos di-

(12) PONTES DE MIRANDA: "Comentários à Constituição de 1946”, vol. III, pag. 265. Ed. Henrique Cañen. 
zer que, com êsse direito está sucedendo o mesmo que se passa com a ilha de HELINGOLAND, da qual as ondas do mar todos os anos levam um pedaço" (13).

As limitações mais importantes, no texto do Código, são aquelas que se prendem à regularização das relações de vizinhança, visando a manutenção de um "statu quo" de proximidade, que interessa a ambos ou a vários vizinhos. A Constituição de 1946, adotando o critério da destinação econômica dos bens, determina, por outro lado, o bom ou máu uso da propriedade em relação ao bem comum. Em suas últimas conseqüências, criaram-se sérios deveres no tocante aos "jura vicinitatis", servidões legais não mais de direito privado, mas de direito público, ou antes, entre pessoas de direito privado e outras de direito público. A Constituição proíbe até o não aproveitamento da propriedade, reduzindo de muito o "jus utendi". Como exemplo da criação de novas servidões, avultam as disposições do Código do Ar, estabelecendo verdadeiras servidões aéreas, com a criação do gabarito de aproximação.

O acobertamento das relações de vizinhança é conseqüência da teoria do abuso do direito, a síntese entre a concepção absolutista dos direitos subjetivos e a relativista. Não se confundem as duas noções, de limitação ao direito de propriedade e a reação ao abuso dêste. Entretanto, o modo como se processava esta reação, condicionado à maneira como se processava o abuso do direito, existente no mundo fático, passou ao jurídico acarretando a transformação de certas reações em li- mitações mesmo ao direito de propriedade. Isto não destruiu, porém, a diferença conceitual jurídica entre as duas idéias, porque novas relações continuam a surgir no mundo dos fatos, não regularizadas expressamente pelo texto legal, e que constituem exemplos de reação ao abuso do direito, sem, contudo, constituirem limitaçōes legais ao direito de propriedade. E a doutrina do código, manifesta na declaração de licitude dos atos praticados em legítima defesa (art. 160). Esclarece PONTES DE MIRANDA: "Estas transformaçōes de regras relativas aos abusos do direito para o campo das regras limitativas do conteúdo do direito de modo nenhum apagam, diminuem a relevância da teoria do abuso do direito" (14). E salienta o grande jurista se a teoria do abuso do direito exatamente para os casos que não foram previstos pela legislação. JOSSERAND agrupa os atos produtores da responsabilidade entre vizinhos em três categorias: ilegais, os que se realizam com a violação de um preceito legislativo ou regulamentar, abusivos, ou, de um modo geral, atos culposos, nos casos em que o proprietário tenha exercido uma prerrogativa que lhe pertencia, mas obedecendo a motivos incorretos, perseguindo uma finalidade que não concorda com a índole do direito, e atos excessivos, os que, realizados em virtude de um direito certo e com fim legítimo, são, não obstante, de tal natureza que causam ao próximo um dano anor-

(13) JOSÉ AUGUSTO CESAR: "Ensaio sôbre os Atos Jurídicos" Campinas, 1913, pag. 17.

(14) PONTES DE MIRANDA: Tratado de Direito Predial, vol. I, 1947, p. 94. 
mal, ou causam perigo (15). O que nos interessa aqui é o fundamento da normatização das relações de vizinhança. A teoria do fundamento social afirma que as relações de ordem privada que se processam no mundo fático sòmente devem entrar para o jurídico quando constituem perturbação ao "statu quo" geral. Ao contrário, individualistas partidários da concepção absolutista dos direitos reais invocam o dever de o mundo jurídico refletir as relações particulares no puro interêsse do indivíduo, abstraindo a coletividade. Mas, como observa EDUARDO ESPINDOLA, "a lei não sanciona os direitos para a pura satisfação dos interêsses egoísticos do indivíduo; ela só lhes reconhece para um fim social, no interêsse comum de todos" (16). Eis a lição de JOSSERAND: "debe establecerse una transacción cuyos términos corresponde fijar al legislador y que se traduce en el establecimiento de nuevas limitaciones aportadas a la propriedad immueble, non ya en el interés de la colectividad, sino también en el de los propietarios vecinos" (17). Eis uma discussão que objetiva conceituações destituidas de interêsse, pois lógico está que a lei agasalha o direito do indivíduo ao mesmo tempo em que atende ao bem estar da coletividade, pois que ambos estão em mútua dependência. $\mathrm{E}$ interêsse da pessoa individual que a paz seja mantida, e esta é conseguida por sua manutenção entre todos. Seja, porém, qual fôr a doutrina invocada, o Código aplicou a teoria do abuso do direito, sendo muito natural que a questão ofereça maior importância em relação às propriedades contíguas, determinan- do os freqüentes e multiformes conflitos de vizinhança, para cuja solução os vários sistemas legislativos estabelecem normas especiais.

Em relação à propriedade das coisas imateriais, fixa o Código normas protetoras da literária, científica e artística, agasalhando a idéia de um direito moral, intimamente. ligado à personalidade do autor. "Lato sensu", a propriedade incorpórea inclui também a industrial e outros bens, como a patrimonialidade de certos ofícios e os direitos sôbre as cartas missivas. No direito brasileiro a propriedade industrial é objeto de lei especial, o Código de Propriedade Industrial, decreto-lei n. ${ }^{\circ} 7903$ de 27-8-45. Quanto ao direito sôbre coisas imateriais, ocorre a limitação quanto ao tempo de exercício. Nossa lei o fixa em sessenta anos, após o falecimento do autor. Note-se que isto não constitui exceção ao princípio da perpetuidade, princípio êste não jusnaturalístico, mas que o uso e aprovação universal até hoje fazem incluir no conteúdo mesmo do direito. E êle se concretiza na faculdade de transmissão hereditária da propriedade. A limitação temporal é uma espécie de desapropriação tácita da propriedade autoral, ditada por motivos de relevante valor social.

O Código de Propriedade In-

(15) LOUIS JOSSERAND: Derecho Civil, t. I, V. III. Ed. Jur. Europa-America, p. 1506.

(16) EDUARDO ESPINDOLA: Posse-Propriedade. Compropriedade ou Condominio, Direitos Autorais. Ed. Conquista, 1956, pág. 236.

(17) JOSSERAND: op. ct. pág. 116, § 1484. 
dustrial preencheu uma lacuna do Código Civil. Entretanto, novas relações fáticas estão a exigir a revisão das disposições. Leis de direito social têm-nas estabelecido referentes ao trabalho, visando a proteção dos fracos e contra a opressão dos poderosos, especialmente do operário contra a ganância de certos patrões que não hesitariam em reduzir ao mínimo as condições necessárias à saúde e tranquilidade familiar daqueles, contanto que lhes trouxesse lucros excessivos. A legislação social é uma conseqüência dêste abuso. Nosso país não experimentou o descalabro de tal situação, resultado de intransigente liberalismo, em tão alto grau como as nações da Europa, em plena revolução industrial, mas assimilou-lhes as conquistas no campo jurídico, visando remediá-la. Entretanto, malgrado a avançada concepção de nossas leis trabalhistas, novas relações estão a exigir novas limitações à propriedade industrial, levando progressivamente à participação dos operários nos lucros e a ter representantes na gestão das emprêsas.

Muito pouco se tem cogitado das limitações à propriedade das fontes produtoras de energia, e destas mesmas. A teoria do abuso do direito vê-se confirmada quando se trata da propriedade de indústrias básicas, aquelaś das quais depende diretamente a segurança do Estado e o bem estar da coletividade, tal a importância que assumem na vida moderna. Urge uma legislação que determine limitações, especialmente à disposição dos lucros fabulosos que tais indústrias geram. $\mathrm{E}$ também quanto à reaplicação de capitais, quan- do se trata de indústrias estrangeiras, impedindo a canalização dêstes lucros para o exterior.

Êste é um dentre os muitos exemplos da insuficiência das disposições vigentes para atender às atuais necessidades. A tendência para o reconhecimento da função social da propriedade pode ser considerada vitoriosa, quer nos moldes jusnaturalistas, de que o homem é um animal social e por isso deve usar da propriedade para o bem comum, ou nos postulados socialistas de que o homem é um administrador da propriedade que lhe atribui o Estado.

Processa-se atualmente um movimento de reforma do Código Civil. Há os que pugnam pela elaboração de um novo estatuto, nos moldes clássicos, com a incorporação das novas relações jurídicas, com a tessetura filosófica mais condizente com o espírito da Constituição, conservando uma lei única que regule as relações de Direito Privado, e há os que simplesmente propõem a extinção do Código Civil, com sua substituição por leis autônomas reguladoras das diversas relações, nos diferentes setôres do Direito Privado; haveria, assim, um Código de Direito de Família, um Código de Obrigações, do mesmo modo que já existe uma Consolidação das leis do Trabalho, um Código de Minas, etc. Embora não escondamos nossa preferência pelo segundo sistema, por razões de ordem prática ditadas pela subordinação das relações de Direito Privado às mudanças de "statu quo", não nos compete no momento discutir os méritos de uma ou outra. O que é imprescindível é a revisão do Estatuto, a transposição do abismo 
que o separa do espírito da Constituição e da nova realidade jurídico-social do país. $\mathrm{E}$ a orientação acêrca do direito de propriedade preconizada pelo Estatuto Magno permite ao jurista a pesquisa no sentido de solucionar os problemas sociais de nosso povo através de uma legislação que atenda àquela orientação e transforme realmente a propriedade em meio de desenvolvimento econômico, intelectual e moral.

5 - Do exposto concluímos a. grande diferença de concepção do Direito de Propriedade, hodiernamente, em relação à vigorante no Corpus Juris Civilis e no Código Napoleônico, no que toca à intangibilidade dêste direito, o individualismo deu lugar às tendências sociais do instituto. Mas profundas modificações se efetuaram quanto à essência mesmo do direito, no modo de sua compreensão institucional, pois, não obstante o individualismo da arcaica concepção, na prática as codificações sempre lhe determinaram restrições, exigidas pelo interêsse geral. A grande evolução se deu sobretudo no modo de encará-lo ontològicamente. Assim é que as doutrinas jusnaturalistas lhe vêm descobrindo, metódica e racionalmente, a razão de ser de sua estrutura, e, partindo do fato de sua presença em todos os estágios da história da humanidade, e ligando-o em suas relações com as necessidades ditadas pela natureza humana, descobre-lhe os fundamentos e lhe lança as premissas de sua real definição. A propriedade tem função social no sentido de que o homem deve atender ao máximo a coletividade, em razão de sua própria natureza social. O estabelecimen- to de tal fundamento às limitações não significa que ela tenha perdido o seu caráter individual e exclusivo, pois, através da gigantesca evolução, os seus elementos essenciais, uso, fruição e disposição permanecem em essência, variando apenas quanto ao âmbito, pois que persiste, de qualquer forma, o direito subjetivo, jusnaturalístico. O Estado, impondo limitações ao livre exercício do direito, o faz à vista do Bem Comum, nunca chegando, porém, a ponto de suprimí-lo, pois que limitar não 'é abolir; as restrições legais são barreiras de defesa da propriedade. O direito de propriedade funda-se na lei natural: corresponde à natureza humana, no sentido de que é necessário à sua própria realização. A natureza social do homem determina limitações ao exercício do direito, a serem fixados pela lei positiva. É o fundamento jusnaturalista da função social da propriedade, determinante das limitações legais.

$\mathrm{Na}$ legislação brasileira, as limitações se processam no sentido do bem estar social, traduzindo a subordinação dos interêsses privados como definitiva conquista do direito. Tais limitações não podem ir a ponto de suprimir o instituto como tal, e, individualmente, a supressão do direito subjetivo só se dará nos casos de desapropriação ou socialização da propriedade particular.

As limitações ao direito de propriedade representam a melhor proteção do instituto, e, acima de tudo, deverão conduzir à sua preservação para o futuro, com uma repartição mais equitativa dos bens. 